\title{
K malakologické charakteristice mokřadů Kokořínska Malacological characteristics of wetlands in the Kokořín Area
}

\author{
Vojen Ložek \\ Nušlova 55/2295, CZ-13000 Praha 13, Stodůlky - Nové Butovice, Česká republika
}

Krom rozlehlých mokřadů chráněných dnes $\mathrm{v}$ přírodních rezervacích Kokořínský důl a Mokřady horní a dolní Liběchovky je v CHKO Kokořínsko řada dalších mokřadů menší rozlohy, z nichž některé rovněž hostí reliktní druhy plžů, zatímco jiné jen běžnou vlhkomilnou malakofaunu (srov. LOžEK 1996). Uvedený rozdíl je dobře patrný z kvantitativních snímků malakocenoz dvou chráněných mokřadních ploch zkoumaných v roce 2002: PP Pod Hvězdou na samém severním okraji Polomených hor pod horou Vlhoštěm (čtverec 5352d) a vstavačová louka pod osadou Blatečky v PP Prameny Pšovky (čtverec 5553b) ve střední části CHKO. Oba hrabankové vzorky byly odebrány 23. 5. 2002 v době květu vstavače májového. Výsledky jejich kvantitativního rozboru shrnují následující seznamy (čísla značí počet exemplářu daného druhu zachycených ve vzorku).

\section{PP Pod Hvězdou}

\begin{tabular}{|l|r|}
\hline Carychium minimum & 143 \\
\hline Carychium tridentatum & 60 \\
\hline Succinea putris & 11 \\
\hline Cochlicopa lubrica & 9 \\
\hline Columella edentula & 4 \\
\hline Vertigo antivertigo & 1 \\
\hline Punctum pygmaeum & 4 \\
\hline Vitrina pellucida & 7 \\
\hline Semilimax semilimax & 2 \\
\hline Perpolita hammonis & 19 \\
\hline Aegopinella pura & 16 \\
\hline Zonitoides nitidus & 3 \\
\hline Euconulus fulvus & 2 \\
\hline Alinda biplicata & 5 \\
\hline Monachoides incarnatus & 2 \\
\hline Cepaea hortensis & 2 \\
\hline Pisidium casertanum & 27 \\
\hline
\end{tabular}

Blatečky, mokřadní louka(PP Prameny Pšovky)

\begin{tabular}{|l|r|}
\hline Galba truncatula & 35 \\
\hline Carychium minimum & 198 \\
\hline Succinea putris & 10 \\
\hline Cochlicopa nitens & 10 \\
\hline Vertigo antivertigo & 12 \\
\hline Vertigo substriata & 4 \\
\hline Vertigo angustior & 6 \\
\hline Punctum pygmaeum & 21 \\
\hline Perpolita hammonis & 8 \\
\hline
\end{tabular}




\begin{tabular}{|l|r|}
\hline Zonitoides nitidus & 25 \\
\hline Euconulus praticola & \\
\hline Cepaea hortensis & 1 \\
\hline Pisidium personatum & 71 \\
\hline
\end{tabular}

\section{Rozbor a komentář $k$ výsledkům odběrů}

V PP Pod Hvězdou je chráněna víceméně zamokřená louka při vyústění suché pískovcové rokle sbíhající z plošiny, na níž leží osada Hvězda. Půda je obohacena průsakem (seepage) z pramenů, střídají se plochy písčité s jílovitými, vegetace má převážně ráz blatouchových vlhčin s tužebníkem jilmovým. Měkkýší společenstvo je sice poměrně bohaté na druhy, ale v podstatě chudé na význačné mokřadní prvky, k nimž zde náleží Carychium minimumm, Succinea putris, Vertigo antivertigo a Zonitoides nitidus, tedy běžné druhy zamokřených ploch, snad s výjimkou $V$. antivertigo, což je heliofilní obyvatel mokrých luk, dnes silně postižený jak melioracemi tak zarůstáním vysokou vegetací, jak ostatně ukazuje i jeho nepatrný podíl v celkovém počtu jedinců. Průvodní fauna již není výrazně mokřadní a pozůstává jak z euryekních druhů jako je Cochlicopa lubrica, Punctum pygmaeum, Vitrina pellucida nebo Euconulus fulvus, tak z druhů převážně lesních jako, Semilimax semilimax, Aegopinella pura, Alinda biplicata, Cepaea hortensis nebo Monachoides incarnatus, z nichž většina běžně proniká i na dostatečně krytá stanoviště v kulturní krajině. Zbytek jsou rovněž druhy s poměrně značným ekologickým rozpětím, většinou s vyššími nároky na vlhkost jako Carychium tridentatum, Columella edentula nebo Perpolita hammonis. Jde tedy o směs druhů schopných prospívat na poměrně široké škále biotopů s výjimkou ploch xerického rázu.

Vstavačová louka u Blateček vykazuje zcela jiné poměry: naprostou převahu mají význačné mokřadní druhy včetně kriticky ohrožené Cochlicopa nitens, vitálních populací 3 zástupců rodu Vertigo a Euconulus praticola. Pozoruhodný je vysoký podíl mokřadního druhu rodu Carychium - C. minimum za úplné absence C. tridentatum i lesních druhů zachycených ve snímku z mokřadu Pod Hvězdou. Jde tedy o význačný reliktní mokřad, který zasluhuje nejpř́snější ochrany včetně pečlivého managementu (kosení), který je zde prováděn, jak bylo zjištěno i při odběru. Mokřady tohoto typu jsou dnes všestranně ohroženy, nehledě k tomu, že i původně u nás byly daleko méně zastoupené než mokřady odpovídající typu Pod Hvězdou, které donedávna byly poměrně běžné.

\section{Summary}

Two different types of molluscan communities from two wetland sites in the Protected Landscape Area of Kokořínsko (Central Bohemia) are described and analysed. The malacocoenosis from the seepage Pod Hvězdou consists of common wetland, catholic and woodland species without relict elements, whereas the Orchis meadow at Blatečky is characterized by endangered relict snails, such as Cochlicopa nitens, Euconulus alderi and both heliophilous Vertigo species $-V$. angustior and $V$. antivertigo as well as by the absence of the above woodland and catholic elements. For this reason the Blatečky meadow represents a relict habitat of high value from the viewpoint of nature conservancy.

\section{Literatura}

LOŽEK V., 1996: CHKO Kokořínsko ve světle výzkumu měkkýšů. - Př́íroda, AOPK, Praha, 7: 169-180. 